\title{
Targeting strategies of adenovirus-mediated gene therapy and virotherapy for prostate cancer (Review)
}

\author{
ZHONGLIN CAI $^{1 *}$, HAIDI LV ${ }^{1 *}$, WENJUAN CAO ${ }^{1 *}$, CHUAN ZHOU $^{2}$, \\ QIANGZHAO LIU ${ }^{3}, \mathrm{HUI} \mathrm{LI}^{4}$ and FENGHAI ZHOU ${ }^{1}$ \\ ${ }^{1}$ Department of Urology, Lanzhou General Hospital of Lanzhou Military Command, Lanzhou, Gansu 730050; \\ ${ }^{2}$ Department of Urology, West China Hospital of Sichuan University, Chengdu, Sichuan 610041; ${ }^{3}$ Department of Urology, \\ Lanzhou University Second Hospital, Lanzhou, Gansu 730000; ${ }^{4}$ Department of Neurosurgery, \\ Lanzhou General Hospital of Lanzhou Military Command, Lanzhou, Gansu 730050, P.R. China
}

Received December 15, 2016; Accepted July 11, 2017

DOI: $10.3892 / \mathrm{mmr} .2017 .7487$

\begin{abstract}
Prostate cancer (PCa) poses a high risk to older men and it is the second most common type of male malignant tumor in western developed countries. Additionally, there is a lack of effective therapies for PCa at advanced stages. Novel treatment strategies such as adenovirus-mediated gene therapy and virotherapy involve the expression of a specific therapeutic gene to induce death in cancer cells, however, wild-type adenoviruses are also able to infect normal human cells, which leads to undesirable toxicity. Various PCa-targeting strategies in adenovirus-mediated therapy have been developed to improve tumor-targeting effects and human safety. The present review summarizes the relevant knowledge regarding available adenoviruses and PCa-targeting strategies. In addition, future directions in this area are also discussed. In conclusion, although they remain in the early stages of basic research, adenovirus-mediated gene therapy and virotherapy are expected to become important therapies for tumors in the future due to their potential targeting strategies.
\end{abstract}

\section{Contents}

1. Introduction

2. Development of a prostate-specific promoter/enhancer to induce expression of therapeutic genes and viral replication that is limited to specific tissues or tumor cells

3. Modification of adenovirus capsid proteins to construct an adenovirus combined with specific cell surface receptors

Correspondence to: Professor Fenghai Zhou, Department of Urology, Lanzhou General Hospital of Lanzhou Military Command, 333 Nanbinhe Road, Qilihe, Lanzhou, Gansu 730050, P.R. China E-mail: 3073142728@qq.com

${ }^{*}$ Contributed equally

Key words: prostate cancer, adenovirus, gene therapy, virotherapy, targeting strategy for infection of specific tissue or tumor cells efficiently deletes partial genes that are essential to adenoviral replication in normal cells but are unnecessary for adenoviral replication in tumor cells

4. Deletion of partial genes that are essential to adenoviral replication in normal cells but are unnecessary for adenoviral replication in tumor cells

5. Clinical research on adenovirus-mediated gene therapy and virotherapy for prostate cancer

6. Future directions

7. Conclusion

\section{Introduction}

Adenoviruses. Adenoviruses are linear and non-enveloped double-stranded DNA viruses. The length of genomic DNA is $\sim 36 \mathrm{~Kb}$, and the gene is divided into coding and non-coding regions. The coding region contains five early transcription units (E1A, E1B, E2, E3 and E4), two delayed transcription units (IX and Iva2) and one late transcription unit (L1-L5). A close association exists between E1 (E1A and E1B) and viral replication. E3 is associated with virus immune evasion and is not important for viral replication. Adenoviruses are divided into seven subgroups, A-G, and human adenoviruses encompass 52 types, of which Ad2 and Ad5 are widely employed in adenovirus studies $(1,2)$.

Adenovirus-mediated gene therapy and virotherapy. Gene therapy and virotherapy involve the introduction of therapeutic genes into tumor cells in order to treat tumors. Adenoviruses that mediate anti-tumor therapy include two types of recombinant adenoviruses, which are replication-deficient adenoviruses (RDAds) and conditional replication adenoviruses (CRAds).

The E1 region consists of the E1A gene, E1B-19 kDa (K) gene and E1B-55K gene. These genes regulate viral replication and the gene expression of other early genes. An adenovirus with deletion of E1 is termed a RDAd due to its lack of self-replication (3-9). In adenovirus-mediated gene therapy, the adenovirus is used as a gene vector to induce the expression of therapeutic genes to inhibit tumor growth. However, the lack of a tumor-targeting effect is problematic; RDAds 
may be transduced into normal cells and cause unpredictable cytotoxicity (10). CRAds, also referred to as oncolytic adenoviruses, is one method used in virotherapy and these viruses are capable of self-replication and the delivery of therapeutic genes $(11,12)$. CRAds contain the E1A region that has a key role in viral self-replication. After CRAds infect tumor cells, the virus is able to replicate itself to generate progeny viruses and induce the expression of therapeutic genes. The tumor cells subsequently die and release CRAds and their progeny viruses, which further infect adjacent tumor cells. However, CRAd-infected normal cells survive as CRAd cannot replicate itself inside these cells (13). The following three major strategies are employed to construct these two types of recombinant adenovirus to enhance tumor-targeting: Development of a tumor/tissue-specific promoter/enhancer to induce expression of therapeutic genes and viral replication that is limited to specific tissue or tumor cells (14); modification of adenovirus capsid proteins to construct an adenovirus combined with specific cell surface receptors that efficiently infects specific tissues or tumor cells, with the deletion of partial genes that are essential to adenoviral replication in normal cells but unnecessary for replication in tumor cells (15); and deletion of partial genes that are essential to adenoviral replication in normal cells but unnecessary for replication in tumor cells (16).

\section{Development of a prostate-specific promoter/enhancer to induce expression of therapeutic genes and viral replication that is limited to specific tissues or tumor cells}

RDAds or CRAds with a prostate-specific promoter or enhancer may exert anti-tumor effects in prostate cancer (PCa) cells only via expression of the therapeutic gene or by oncolysis. Evidence of recombinant adenoviruses with a prostate-specific promoter or enhancer is presented in Table I.

Prostate-specific antigen (PSA). PSA is present in the cytoplasm of prostatic duct epithelial cells and prostate gland cells, and PSA expression has been observed in normal prostate tissues and PCa cells. PSA is the primary biomarker used to monitor PCa. PSA is also employed to screen patients with $\mathrm{PCa}$ and monitor the recurrence of $\mathrm{PCa}$ following treatment (17-21). CV706 is the first oncolytic adenovirus with the PSA promoter. The PSA promoter drives the expression of E1A and causes the oncolytic adenovirus to replicate in PSA-positive PCa cells and induce oncolysis. However, the ability to self-replicate was low in PSA-negative PCa cells, and its progeny virus production was also low $(22,23)$. In phase I clinical trials, treatment with CV706 was applied to patients with local $\mathrm{PCa}$ following radiotherapy, and the results demonstrated a marked decrease in PSA levels and a satisfactory antitumor effect (24). Wang et al (25) developed a recombinant adenovirus that expressed $\beta$-glucuronidase $(\beta \mathrm{G})$ under the control of the PSA promoter (Ad/PSAP-GV16- $\beta$ G). The prodrug DOX-GA3, N-[4-doxorubicin-N-carbonyl (oxymethyl) phenyl] O- $\beta$-glucuronyl carbamate, is converted into toxic DOX by $\beta \mathrm{G}$. The results of an MTT assay indicated that the oncolytic virus induced significant oncolysis in LNCaP PCa cells, however, the same effect was not observed in PSA-negative DU145 PCa cells. In addition, intravenous injection of Ad/PSAP-GV16- $\beta$ G and treatment with DOX-GA3 efficiently inhibited the growth of LNCaP cell xenograft tumors in nude mice. These results demonstrated the efficacy of the PSA promoter in adenovirus-mediated gene therapy and virotherapy against PSA-producing PCa.

Probasin $(P B)$. PB is a member of the lipocalin superfamily and is a type of ligand transporter. $\mathrm{PB}$ is isolated from the nucleus of the dorsal lateral lobe of the rat prostate and is located in the ducts and nucleus of prostate epithelial cells $(26,27)$. As such, PB exhibits tissue specificity, and experiments have demonstrated that a PB promoter may be regulated by androgens and drive the expression of foreign genes in PCa cells in vitro and prostate tissue in vivo (28). Trujillo et al (29) developed a CRAd with PB and Rous sarcoma virus (RSV) promoters that drove the expression of the E1 gene, and NIScDNA-bGH polyA that replaced the E3 region (CRAd Ad5PB_RSV-NIS). In vitro, infection of $\mathrm{LNCaP}$ PCa cells by the CRAd led to virus replication and cytolysis, and the release of infective viral particles. However, androgen receptor (AR)-negative PC-3 cells (PCa cell line) and Panc-1 cells (pancreatic cancer cell line) infected by the CRAd demonstrated no virus replication or cytolysis. In vivo, intratumoral injection with the CRAd and administration of therapeutic ${ }^{131}$ iodine in nude mice carrying LNCaP cell xenograft tumors markedly inhibited tumor growth and increased nude mice survival rates. As the RSV promoter induces the expression of therapeutic genes, it may be employed to target cancer cells and normal cells and tissues, and the RSV promoter has a low targeting effect (10). The above results demonstrate that the $\mathrm{PB}$ promoter is a prostate-specific promoter. The RDAd (Ad-ARR2PB-Bax) expressed the apoptotic $\mathrm{Bcl} 2$-associated $\mathrm{X}$ (Bax) gene driven by a PB promoter containing two androgen response elements (ARR). Following infection of LNCaP cells with Ad-ARR2PB-Bax, androgen dihydrotestosterone induced Bax-mediated apoptosis. This antitumor effect of RDAd was also observed in LNCaP xenograft tumors (30). These results indicate that adenoviruses with a $\mathrm{PB}$ promoter may employed to target AR-positive PCa.

Prostate-specific membrane antigen (PSMA). PSMA is a type 2 intrinsic membrane protein on prostatic epithelial cells that is homologous with the serum transferrin receptor. PSMA is primarily expressed in PCa cells and is highly expressed in PCa and during metastasis (31-37). Gao et al (38) constructed a recombinant adenovirus that expressed human sodium iodide symporter (hNIS) driven by the PSMA promoter (Ad. PSMApro-hNIS). Compared with the recombinant adenovirus containing a cytomegalovirus (CMV) promoter (Ad. CMV-hNIS), expression of the hNIS gene induced by the PSMA promoter was highly prostate-specific in different LNCaP cell lines, particularly in the androgen-independent C81 LNCaP cell line. The antitumor effect of radioiodine therapy was improved in $\mathrm{C} 81$ cell xenografts in nude mice that received PSMA promoter-driven hNIS transfection compared with CMV promoter-driven hNIS transfection. A recombinant adenovirus, combined with the prodrug 5-fluorocytosine, was developed to express the cytosine deaminase (CD) gene driven by a PSMA promoter and enhancer [Ad-PSMA (E-P)-CD]. This treatment caused PSMA-producing PCa cells ( $\mathrm{LNCaP}$ and CL-1) to regress and efficiently inhibited the growth of 


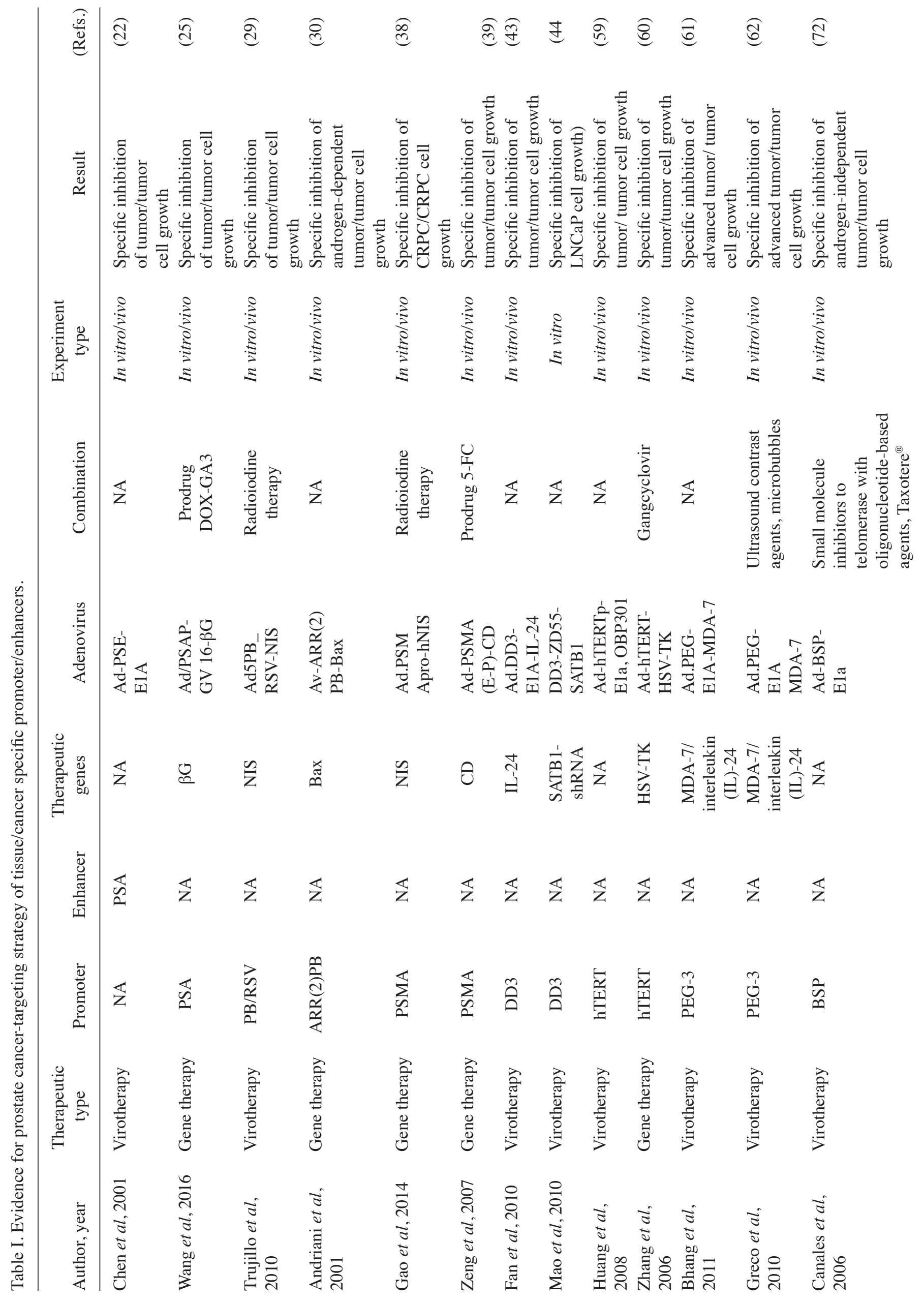




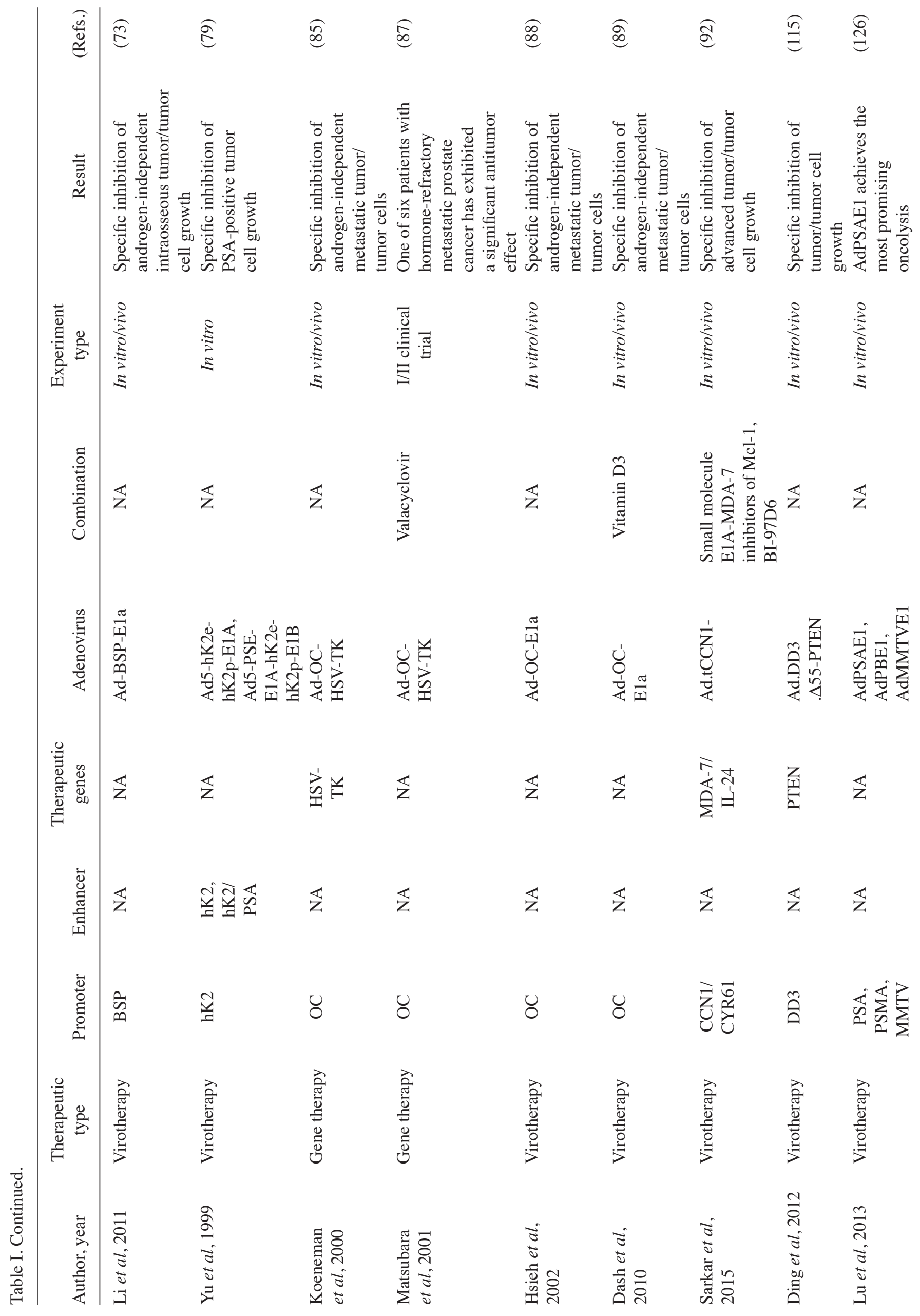


CL-1 xenograft tumors. These results indicate that the PSMA promoter may be an important prostate-specific promoter for adenovirus-mediated treatment of PSMA-positive PCa cells (39).

Prostate cancer gene 3 (PCA3). PCA3 is a type of long non-coding RNA that is one of the PCa-specific markers discovered in recent years. Overexpression of PCA3 occurs in $>95 \%$ of primary $\mathrm{PCa}$ and metastatic cancer specimens, and is not observed in other normal tissues (40-42). Fan et al (43) developed two plasmids containing the differential display code (DD) 3 of PCA3 promoter and the PSA promoter (pGL3-DD3 and pGL3-PSA, respectively). Luciferase activity demonstrated that the DD3 promoter and the PSA promoter exhibited similar activity in the LNCaP PCa cells. However, the DD3 promoter exhibited $\sim 2$-fold higher activity compared with the PSA promoter in DU145 PCa cells. In non-PCa cell lines, the DD3 promoter exhibited a lower activity compared with the PSA promoter. Therefore, the results indicated that the DD3 promoter is more PCa-specific. Furthermore, two oncolytic adenoviruses were developed to express interleukin (IL)-24 driven by the DD3 promoter and the PSA promoter (Ad.DD3-E1A-IL-24 and Ad.PSA-E1 A-IL-24, respectively). In vitro and in vivo, the antitumor effect of Ad.DD3-E1A-IL-24 was higher compared with Ad.PSA-E1A-IL-24. Further experiments demonstrated that the PCa specificity of the DD3 promoter was higher. Mao et al (44) reported that the expression of the E1A gene driven by the DD3 promoter of Ad-DD3-E1A occurred in LNCaP PCa cells and not in non-PCa cell lines (BT549 and RWPE2). These results indicate that the DD3 promoter may be useful as a PCa-specific promoter with applications for PCa-targeting by adenovirus-mediated therapy.

Human telomerase reverse transcriptase (hTERT). Telomeres maintain cell chromosome stability and cell activity. Telomere activity is inhibited in normal cells, however, telomerase is reactivated in the majority of human tumor tissues (45-48). High activity of TERT occurs in PCa. However, the activity of TERT is low or absent in normal or benign prostatic hyperplasia tissue (49-52). OBP-301 is an oncolytic virus that contains the hTERT promoter (53-55). OBP-401 is an oncolytic virus that expresses green fluorescent protein (GFP) under control of the hTERT promoter (55-58). When OBP-401 was employed to infect different PCa cell lines (PrEC, PrSC, LNCaP, PC3 and DU145), the expression of GFP occurred in LNCaP, PC3 and DU145 PCa cell lines, but not in PrEC and PrSC normal prostate cell lines. Intratumoral injection with OBP-301 significantly inhibited LNCaP cell xenograft tumors in nude mice. In addition, histological and immunohistochemical analyses demonstrated diffuse oncolysis of tumor cells and the expression of the E1A protein in the tumors (59). Zhang et al (60) developed a recombinant adenovirus that expressed the herpes simplex virus-thymidine kinase (HSV-TK) gene driven by the $h$ TERT promoter (Ad-hTERT-HSV-TK). Ad-hTERT-HSV-TK, combined with ganciclovir (GCV), effectively suppressed the growth of LNCaP cell xenograft tumors in nude mice. These results demonstrate that the hTERT promoter is a $\mathrm{PCa}$-specific promoter that may be useful in improving the PCa-targeting effect. 
Progression elevated gene-3 (PEG-3). PEG-3 was identified through subtraction hybridization of E11 or E11-NMT cell xenograft tumors during the search for genes involved in malignant transformation and tumor progression. Various trans-acting factors activate PEG-3 in a number of human cancers, including $\mathrm{PCa}$, breast and skin cancer, with limited activity observed in normal tissues. Therefore, PEG-3 exhibits tumor specificity (61-65). Sarkar et al (66) constructed an oncolytic adenovirus expressing the melanoma differentiation-associated protein 7 (MDA-7)/IL-24 driven by the PEG-3 promoter (Ad.PEG-E1A-mda-7). Prostatic epithelial cells infected by Ad.PEG-E1A-mda-7 exhibited no expression of E1A and MDA-7, however, expression was observed in LNCaP, DU145 and PC-3 PCa cell lines infected by Ad.PEG-E1A-MDA-7. Ad.PEG-E1A-MDA-7 also markedly inhibited the growth of DU145 cell xenograft tumors in vitro and in vivo (66). Greco et al (62) combined Ad.PEG-E1A-MDA-7 with ultrasound contrast agents (microbubbles) to improve the PCa-targeting effect of the oncolytic adenovirus via ultrasonic guidance. The results demonstrated that microbubble/Ad.MDA-7 complexes markedly reduced the tumor burden in DU145 cell xenograft tumors in nude mice. These results indicate that use of the PEG-3 promoter in the recombinant adenovirus selectively induces the expression of therapeutic genes in $\mathrm{PCa}$.

Bone sialoprotein (BSP). BSP, an acid glycoprotein that is a member of the small integrin-binding, N-linked glycoproteins family, is abundant in the extracellular matrix and is secreted by osteoblasts and osteoclasts $(67,68)$. BSP is associated with the occurrence and development of tumors, and high expression of BSP has been reported in breast cancer, PCa, lung cancer, melanoma and other types of bone metastases (69-71). Canales et al (72) developed an oncolytic virus containing the BSP promoter (Ad-BSP-E1a). The oncolytic adenovirus, combined with small molecule antisense oligonucleotide-based inhibitors (GRN163) and Taxotere ${ }^{\circledR}$ (Sanofi S.A., Paris, France), markedly inhibited the growth of the C42B PCa cell line. In addition, Li et al (73) reported that the oncolytic adenovirus (Ad-BSP-E1a) inhibited C42B growth and also decreased PSA levels in vitro. In vivo, the oncolytic adenovirus suppressed the growth of subcutaneous and intraosseous xenograft tumors of the C42B PCa cell line in nude mice (73). These results indicate that the recombinant adenovirus with the BSP promoter has PCa specificity and that CRAds with the BSP promoter have potential for the oncolysis of advanced $\mathrm{PCa}$.

Human kallikrein 2 ( $h K 2$ ). hK2 is a serine protease that is member of the hK family that consists of a highly conserved sequence. hK2 is primarily produced by prostate epithelial cells $(74,75)$ and is also expressed in breast, ovary, testis and other tissues, however, its expression is higher in prostate tissue (75-77). A previous study demonstrated that the hK2 protein was expressed in PSA-negative prostate tumors and in each tumor cell (78). As a result, in addition to PSA, hK2 is considered to be an important marker of PCa. An oncolytic adenovirus mutant that expressed E1A under control of the hK2 promoter/enhancer was referred to as CV763. A study demonstrated that replication of CV763 was notably high in PSA-positive prostate tumor cells, but was attenuated in
PSA-negative and non-prostate tumor cells. CV763 containing the PSA enhancer was referred to as CV764, and exhibited a higher therapeutic index for PSA-positive LNCaP PCa cells (79). The above results indicate that the adenovirus with the hK2 promoter may improve PCa specificity.

Osteocalcin (OC). OC, which is secreted by osteoblasts, is a marker of bone metabolism, and bone is the most common metastatic tissue of advanced PCa. The activity of osteoblasts is closely associated with bone metastasis of tumors. Therefore, OC produced by osteoblasts is also associated with the progression of $\mathrm{PCa}$ bone metastasis. Compared with PSA, $\mathrm{OC}$ has a high sensitivity and specificity for diagnosing $\mathrm{PCa}$ bone metastasis (80-84). Koeneman et al (85) constructed an RDAd that expressed HSV-TK driven by the OC promoter (Ad-OC-TK). Ad-OC-TK combined with GCV effectively destroyed PCa cell lines in vitro and PCa xenografts in vivo, in subcutaneous and bone sites. In phase I clinical trials, patients with local metastasis of PCa were treated with Ad-OC-TK. The results demonstrated that all patients reported an absence of severe side effects, and PCa cell death was observed during treatment (86). Matsubara et al (87) reported that an oncolytic adenovirus with the OC promoter effectively inhibited the growth of PCa cell lines (LNCaP, C4-2 and ARCaP). In addition, in vivo, this oncolytic adenovirus also markedly suppressed intraosseous xenograft tumors, and PSA levels decreased without a subsequent rebound. Furthermore, combination with vitamin D3 significantly enhanced the antitumor effect of Ad-OC-E1A (88). These results indicate that the recombinant adenovirus containing the OC promoter may be a promising treatment strategy for advanced $\mathrm{PCa}$.

CCN1/CYR61 gene. Elevated expression of the CCN1/CYR61 gene occurs in various cancers, such as advanced PCa, due to oncogenic transformation, and this expression increases with the aggressiveness of the transformed cells (89-91). Sarkar et al (92) developed a recombinant adenovirus that expressed MDA-7/IL-24 driven by a truncated (t)CCN1 promoter (Ad. CCN1-CTV-m7). The MDA-7/IL-24 gene under the control of the tCCN1 promoter of Ad.tCCN1-CTV-m7 exhibited high expression in $\mathrm{PCa}$ cells. In vitro, the Ad.tCCN1-CTV-m7 exerted a dose-dependent killing effect on PCa cells without injury to normal prostatic epithelial cells. In vivo, Ad.tCCN1-CTV-m7 significantly suppressed $\mathrm{PCa}$ cell xenograft tumors in transgenic Hi-Myc mice when combined with ultrasound-targeted microbubble-destruction. Furthermore, Ad.tCCN1-CTV-m7 combined with small molecule inhibitors of Mcl-1, and BI-97D6, improved apoptosis and tumor growth suppression in Hi-myc mice. These results indicate that the adenovirus with the tCCN1 promoter improved the PCa-targeting effect of the adenovirus and the ability of other treatments to destroy PCa cells.

Combination of promoter and/or enhancer. The combination of a promoter and/or enhancer is a common targeting strategy used to improve $\mathrm{PCa}$ specificity of recombinant adenoviruses (Table II). Lee et al (93) developed an RDAd with a prostate-specific enhancing sequence (PSES) promoter that consisted of a PSA enhancer and PSMA enhancer (Ad-PSES-luc). Luciferase analysis demonstrated that high 


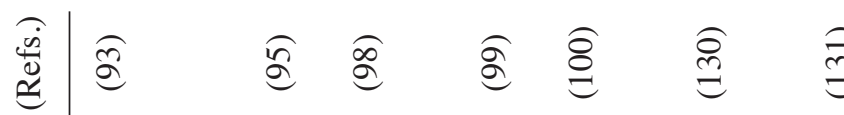

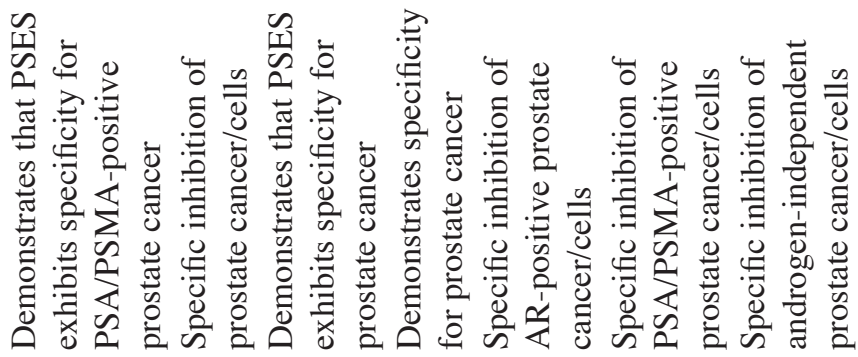

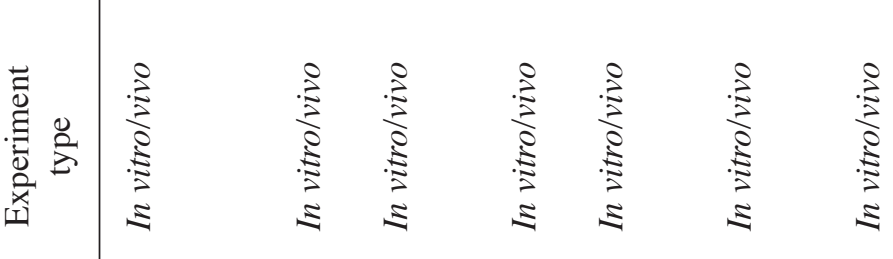

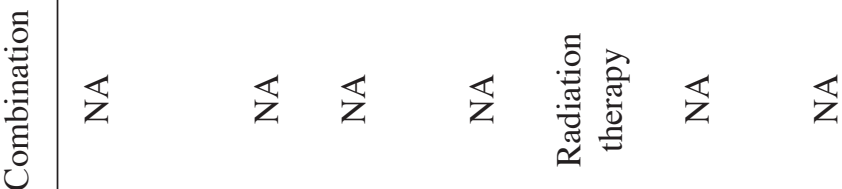

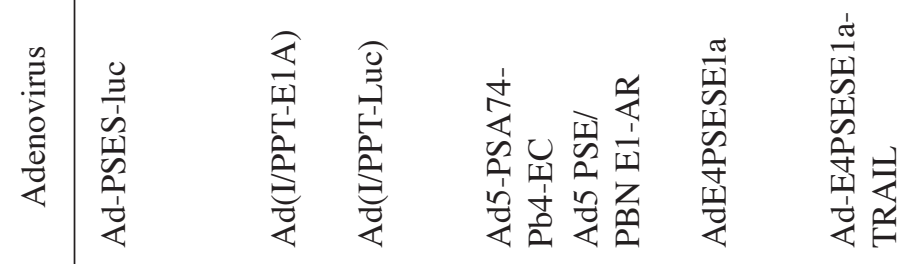

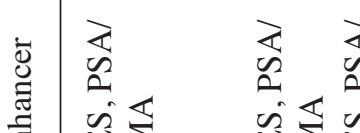

$\begin{array}{llllll}\mathbb{z} & \mathbb{z} & \mathbb{z} & \mathbb{z} & \mathbb{z} & \mathbb{2}\end{array}$

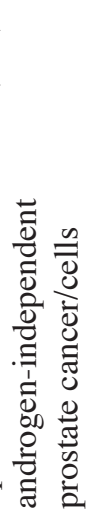

政

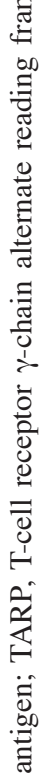

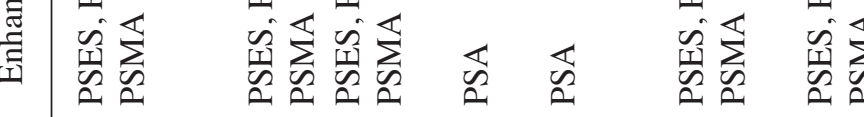

芯

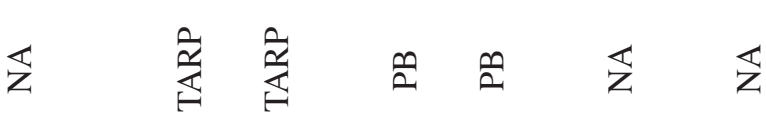

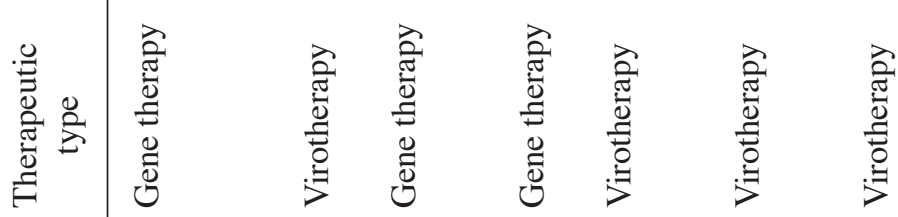

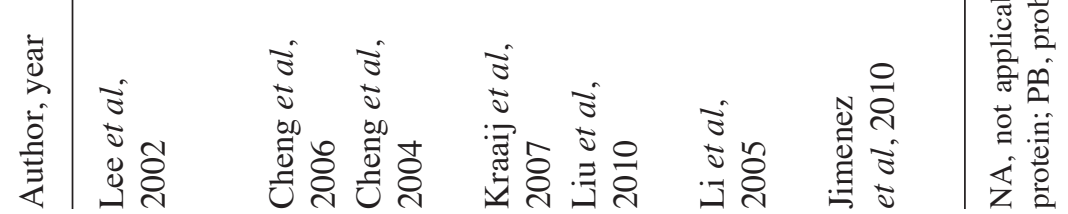


expression of the luciferase gene occurred in PSA- and PSMA-expressing PCa cell lines in vitro following infection with Ad-PSES-luc. In vivo, when Ad-PSES-luc was injected into the prostate, high luciferase activity occurred in the prostate, but not in other tissues. The expression of T-cell receptor $\gamma$-chain alternate reading frame protein (TARP) is specific to prostate epithelial cells and PCa cells. The PPT promoter containing the PSA enhancer, the PSMA enhancer and the TARP promoter demonstrates a high specificity for the prostate. The H19 insulator is introduced upstream of the PPT sequence to protect the PPT promoter from transcriptional interference from adenoviral backbone sequences (94-97). Cheng et al (98) constructed an adenovirus vector that expressed the luciferase gene under control of the PPT promoter with the H19 insulator [Ad(I/PPT-Luc)]. The I/PPT promoter generated high activities in testosterone-deprived PCa cells and PC-346C PCa cell orthotopic xenograft tumors in nude mice. Cheng et al (95) also reported that an oncolytic adenovirus [Ad(I/PPT-E1A)] that infected hormone-dependent and hormone-independent PCa cell lines induced expression of the E1A protein, virus replication and cytolysis in vitro, and the growth of LNCaP cell xenograft tumors in nude mice was markedly inhibited in vivo. Furthermore, the recombinant adenovirus with the PPT promoter, a two-step transcriptional amplification (TSTA) system, amplified [Ad(PPT/TSTA-Luc)]-enhanced prostate-specific transcriptional activity (97), and the Ad (I/PPT-E1A) with a reintroduced full-length E3 region [Ad (i/PPT-E1A, E3)] improved the cytopathic effect and suppression of PCa growth (96). Kraaij et al (99) reported that replication of an adenovirus with the PSA enhancer and the PB promoter (Ad5-PSA74-Pb4-EC) was observed in PCa cells. In addition, an oncolytic adenovirus with the PSA enhancer and the PB promoter (Ad5 PSE/PBN E1-AR), combined with low/high dose-rate radiation, exerted marked adenovirus-mediated PCa cell death (100). Furthermore, Yu et al (79) developed an oncolytic adenovirus with the PSA enhancer and the hK2 promoter (CV764). Compared with CV763, CV764 enhanced the inhibitory effects on $\mathrm{PCa}$ in vitro and in vivo. These results demonstrate that a recombinant adenovirus combined with an enhancer and/or promoter produces a higher targeting effect and enhancement of the antitumor effects, which may indicate that adenoviruses combined with other treatments may improve PCa specificity and the suppression of growth.

\section{Modification of adenovirus capsid proteins to construct an adenovirus combined with specific cell surface receptors for infection of specific tissue or tumor cells efficiently deletes partial genes that are essential to adenoviral replication in normal cells but are unnecessary for adenoviral replication in tumor cells}

Recombinant adenoviruses with modification of adenovirus capsid proteins may enhance the ability to infect PCa cells by binding to the novel receptors on the surface of the cells. Evidence of recombinant adenoviruses with modification of the adenovirus capsid proteins is presented in Table III.

Species $\mathrm{C}$ adenoviruses, such as Ad2 and Ad5, infect cells via Coxsackie-adenovirus receptors (CARs) on the cell surface (101). Different levels of CAR expression have been observed in various tumor types and CAR expression is downregulated in a number of tumors, such as CAR-negative $\mathrm{PCa}$, which results in inefficient Ad-mediated therapeutics (101). Incorporation of an arginine-glycine-aspartic acid (RGD) peptide into the HI loop of the adenovirus fiber knob allows adenoviruses to infect CAR-negative PCa cells via cell-surface integrin $\alpha v \beta 3 / 5$, which is expressed by all PCa cell lines (101). Suzuki et al (101) developed an adenovirus mutant with an RGD-fiber modification (Ad5- 2 24RGD). Compared with an adenovirus mutant without the RGD-fiber modification (Ad5- $\Delta 24)$, Ad5- $\Delta 24 R G D$ exhibited a higher infection ability and an anti-PCa effect. A number of studies involving recombinant adenoviruses with RGD-fiber modification further confirmed that the RGD-modified adenovirus may enhance the PCa-targeting effects in vitro and in vivo (102-105).

The generation of chimeric adenoviruses, in which one adenovirus fiber knob is replaced with a different adenovirus fiber knob, may alter the orientation of the adenovirus and enhance transduction targeting to improve the tumor cell infection efficiency. Azab et al (106) constructed a recombinant adenovirus in which the fiber knob was replaced with an Ad.3 fiber knob, and this construct expressed the MDA-7/IL-24 gene (Ad.5/3-CTV). Compared with Ad.5-CTV, Ad.5/3-CTV exhibited a higher efficiency in inhibiting the viability of low-CAR human PCa cells in vitro, and also potently suppressed low-CAR PCa cell xenograft tumors in vivo. It has been reported that the Ad.3 receptor is highly expressed in tumor cells (107). Ad.5/3 infected the tumor cells via the Ad.3 receptor instead of CAR, and, therefore, it was able to infect tumor cells with low or no expression of CAR (107-109). Systemic treatment with Ad.5 is associated with serious hepatotoxicity and systemic toxicity (110). Xu et al (110) developed a chimeric oncolytic adenovirus that expressed soluble transforming growth factor $\beta$ receptor II-Fc fusion protein (sT $\beta R F c)$, the chimeric oncolytic adenovirus in which seven hypervariable regions of Ad.5 were substituted with the corresponding sequence of Ad48 (mHAd.sT $\beta \mathrm{RFc}$ ). In vivo, mHAd.sT $\beta \mathrm{RFc}$ retained an inhibitory effect on PC-3 PCa bone metastases in nude mice, and also reduced the hepatotoxicity and systemic toxicity to indirectly improve the tumor-targeting effect. Serotype 35 adenoviruses infect cells through cell surface CD46 receptors, which are widely expressed on normal and cancer cells (111). Kim et al (111) constructed a novel chimeric recombinant adenovirus expressing monomeric red fluorescence protein (mRFP)/modified HSV-TK (ttk) (Ad5/35PSES. $\mathrm{mRFP} / \mathrm{ttk}$ ), which was driven by PSES and featured the serotype 35 fiber knob on the serotype 5 backbone. This chimera improved the cell infection efficiency, and the PSES enhanced the PCa-targeting effect. In vitro, replication assays demonstrated that Ad5/35PSES.mRFP/ttk replicated in PSES-positive PCa cells (LNCaP and CWR22rv) but not in PSES-negative PCa cells (DU145 and PC3). Evaluation of the cytotoxic activity demonstrated that Ad5/35PSES.mRFP/ttk killed LNCaP and CWR22rv cells more effectively. In addition, the chimeric oncolytic adenovirus Ad5/35E1aPSESE4 also effectively killed PSA/PSMA-positive PCa cells in the peripheral circulation (112).

4. Deletion of partial genes that are essential to adenoviral replication in normal cells but are unnecessary for 


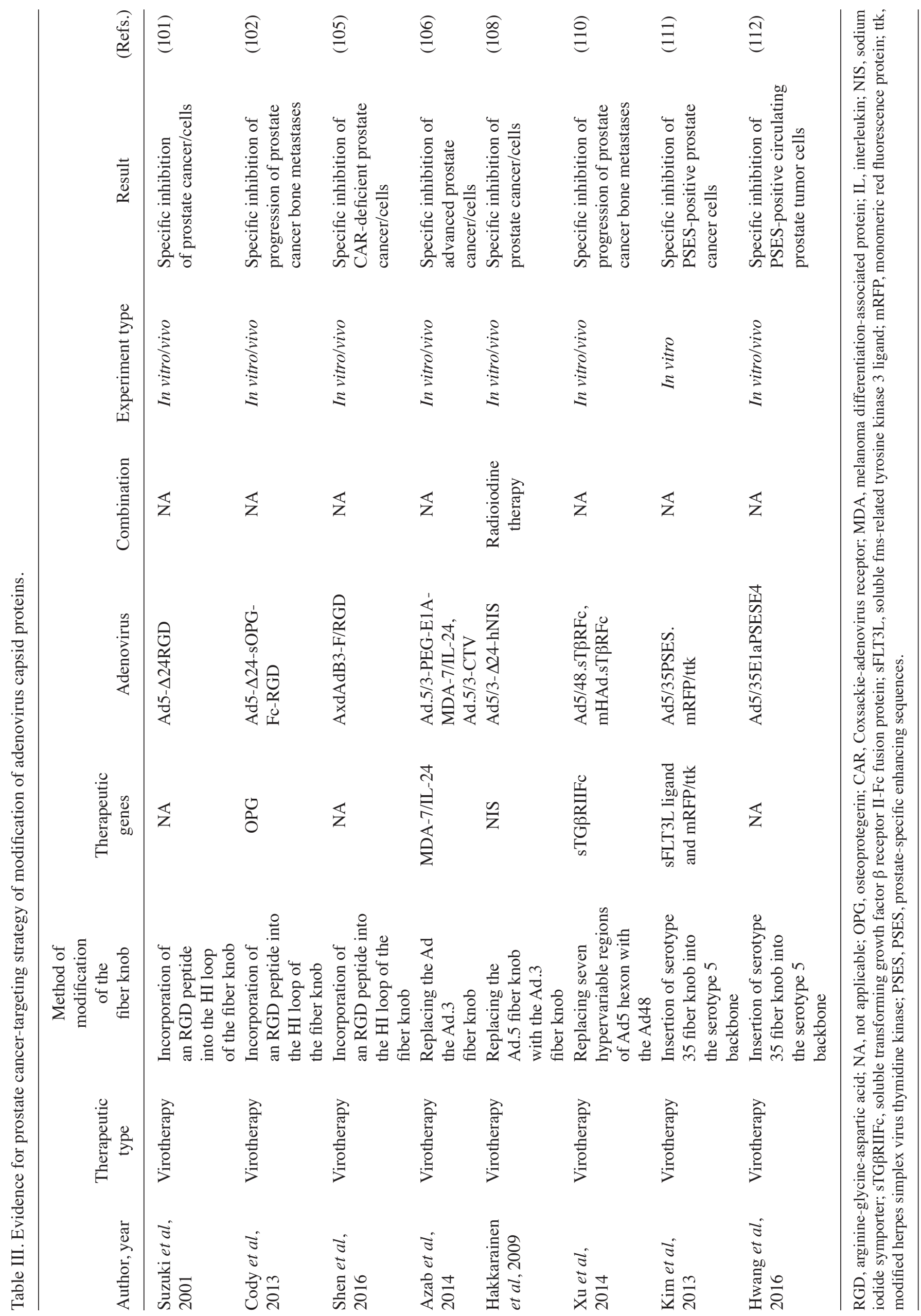




\section{adenoviral replication in tumor cells}

Binding of E1B-55K protein to the p53 gene inhibits p53-mediated normal cell apoptosis, therefore, oncolytic adenoviruses with the E1B-55K gene are able to survive in normal cells (113-115). Oncolytic adenoviruses with deletion of the E1B-55K gene have the ability to survive in tumor cells in which no apoptosis occurs due to $\mathrm{p} 53$ gene mutations or deficiency. However, oncolytic adenoviruses with deletion of the E1B-55K gene cannot survive in normal cells due to p53-mediated apoptosis (113). Mao et al (114) developed an oncolytic adenovirus with deletion of the E1B-55K gene, the oncolytic adenovirus that expresses short hairpin RNA targeting SATB homeobox 1 (SATB1; ZD55-SATB1). ZD55-SATB1 markedly inhibited the viability and invasion of PCa cell lines DU145 and LNCaP, and suppressed PCa growth and metastasis in xenograft nude mice. Ding et al (115) reported that an oncolytic adenovirus mutant with the DD3 promoter and deletion of the E1B-55K gene, termed Ad.DD3.A55-PTEN, expressed phosphatase and tensin homolog (PTEN) to induce PCa cell apoptosis and inhibit the growth of xenograft tumors, however, Ad.DD3. $\triangle 55-\mathrm{PTEN}$ had no death-inducing effects in non-PCa cell lines.

The E1A conserved region 2 (E1A-CR2) normally binds to host cell retinoblastoma $(\mathrm{Rb})$ protein and releases transcription factor E2F, enabling S-phase entry and viral DNA replication. Oncolytic adenovirus E1A-CR2 (Rb-family binding site) mutants do not bind to $\mathrm{Rb}$ protein to induce normal cells to enter $\mathrm{S}$ phase and, therefore, are unable to efficiently replicate in quiescent normal tissues. However, oncolytic adenovirus E1A-CR2 mutants are able to replicate in tumor cells with $\mathrm{Rb}$ gene mutations as tumor cell growth is not solely dependent on $\mathrm{Rb}$ protein (14). In addition, adenovirus E1A-CR2 mutants combined with cytotoxic drugs (116) or radiotherapy (108) significantly enhance the inhibitory effect on castration-resistant $\mathrm{PCa}$. A novel oncolytic adenovirus mutant with deletion of E1A-CR2 and E1B-19K, referred to as $\operatorname{Ad} \Delta \mathrm{CR} 2 \Delta 19 \mathrm{~K}$, demonstrated high cytotoxic effects in PCa, pancreatic cancer and lung cancer, and the replication ability of $\operatorname{Ad} \Delta \mathrm{CR} 2 \Delta 19 \mathrm{~K}$ in tumor cells was similar to that of the wild-type virus (117). Radhakrishnan et al (116) constructed an oncolytic adenovirus mutant with deletion of E1A-CR2 and E3B (d1922-947). Compared with dl312 ( $\triangle \mathrm{E} 1 \mathrm{~A}$ and $\triangle \mathrm{E} 3 \mathrm{~B})$, d11520 ( $\Delta$ E1B-55K and $\Delta \mathrm{E} 3 \mathrm{~B})$ and Ad5 (wild-type), d1922-947 exhibited the highest antitumor effect in hormone-independent PCa in vitro and in vivo. The combination of d1922-947 with low doses of mitoxantrone or docetaxel enhanced the efficacy. Furthermore, Satoh et al (118) developed a double-mutated adenovirus with a mutation in E1A-CR2 and deletion of E1B-55K (AxdAdB-3).In vitro, AxdAdB-3 exhibited a potential cytopathic effect in different $\mathrm{PCa}$ cell lines and demonstrated no cytotoxicity in PrEC and PrSC normal prostate cell lines. In vivo, AxdAdB-3 markedly inhibited the growth of PCa cell xenograft tumors in nude mice and improved survival.

Adenovirus mutants have substantial effects on the inhibition of the growth of $\mathrm{PCa}$ and a number of mutations in the E1 region of the adenovirus are associated with these effects. A list of adenovirus mutants is presented in Table IV.

\section{Clinical research on adenovirus-mediated gene therapy}

\section{and virotherapy for prostate cancer}

Currently, viral gene therapy is an area of increasing interest in the field of tumor therapy. Adenovirus-mediated gene therapy and virotherapy are among the most common research areas in viral gene therapy. As these therapies have demonstrated satisfactory anti-PCa effects in basic experiments, clinical trials have been performed. DeWeese et al (119) performed a phase I clinical trial in which 20 patients with PCa who had relapsed following radiotherapy were treated with CRAd CV706. The clinical results demonstrated a satisfactory treatment effect on $\mathrm{PCa}$ without the presence of severe side effects. In addition, Freytag et al (120) constructed an oncolytic virus (ZD55-CD/TKrep) with deletion of E1B-55K and expression of the suicide gene $\mathrm{CD} / \mathrm{TK}$ rep, which was employed to salvage therapy for 16 patients with PCa who had relapsed following radiotherapy. The clinical results indicated good safety and efficacy. A total of 16 patients were followed for 5 years and the survival rate was $88 \%$ (14/16 patients). Furthermore, Freytag et al (121) used an oncolytic virus (ZD55-CD/TKrep) combined with external radiotherapy to treat 15 patients with high-risk PCa. The results demonstrated that the effect of combined therapy was higher compared with radiotherapy alone, however, contradictory clinical effects have also been reported regarding PCa in clinical trials. Small et al (122) conducted a phase I trial of intravenous CG7870 to treat hormone-refractory metastatic PCa. The results indicated a poor treatment effect, and patients with decreased serum PSA levels accounted for only $5 / 23$ patients with PCa. However, no obvious side effects were observed in the 23 patients. Although the majority of clinical trials concerning adenovirus-mediated gene therapy and virotherapy have demonstrated good antitumor effects, biosafety issues arise with adenovirus treatments, particularly tumor-targeting treatments, which limits clinical applications. Consequently, clinical trials involving adenovirus treatments have been stalled in phase I clinical trials. Currently, only one type of oncolytic adenovirus, H101 with deletion of E1B-55K, has been approved for use in patients with advanced tumors, and this approval is only in China.

\section{Future directions}

Although adenoviruses constructed by different targeting strategies have demonstrated satisfactory targeting effects in the treatment of $\mathrm{PCa}$, each targeting strategy is associated with certain limitations. The combined use of multiple targeting strategies to enhance the adenovirus targeting effect is one promising direction. Currently, several experiments with adenoviruses constructed using multiple targeting strategies have demonstrated that the adenoviruses markedly improve targeting and antitumor effects, including AxdAdB3-F/RGD (105) with RGD-fiber modification and the E1A/E1B double mutation, Ad5/3- $\Delta 24-h N I S$ (108) with the hybrid Ad5/3 fiber and 24-bp deletion in the E1A-CR2, and DD3-ZD55-SATB1 (114) with the DD3 promoter and E1D-55 K deletion, among others. Therefore, the joint use of targeting strategies is an important direction towards enhanced tumor targeting. A list of the adenoviruses constructed using multiple targeting strategies is presented in Table V. 


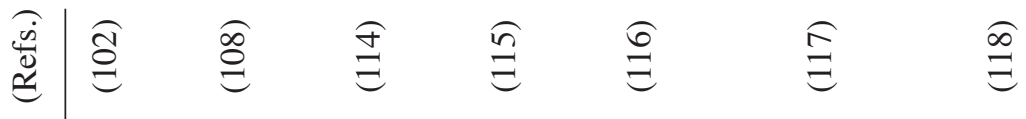

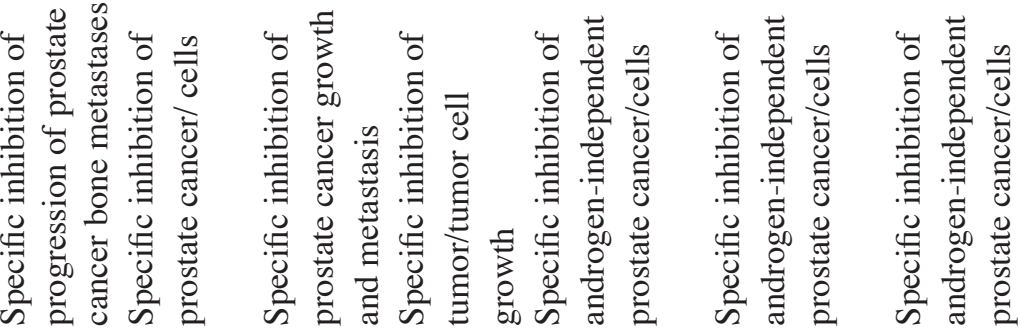

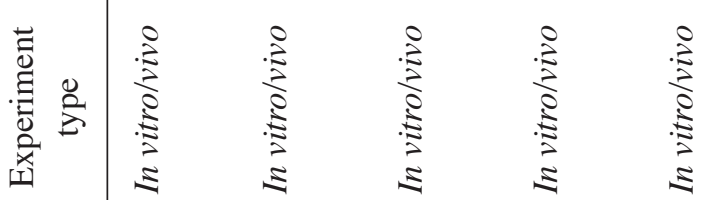

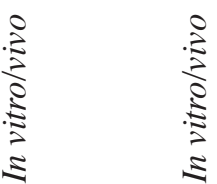

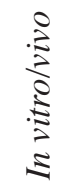

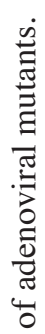

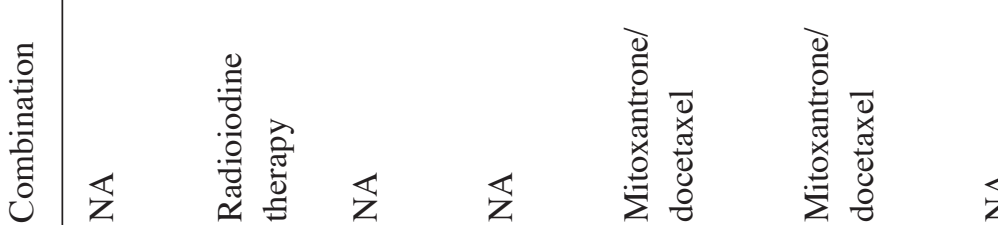

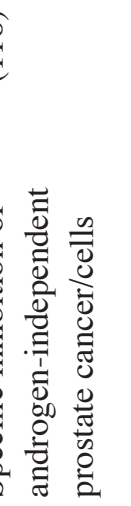

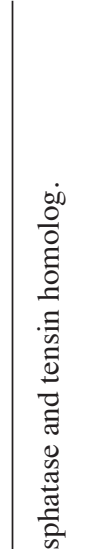

a

焉

荬 论

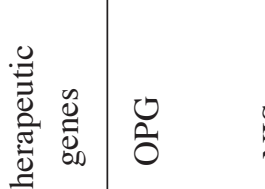

F

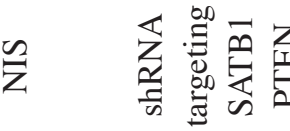

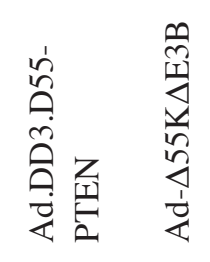

$\frac{y}{2}$

$\varangle$

$\frac{\hat{n}}{0}$

$\exists \overline{8} \quad \Xi \overline{0}$

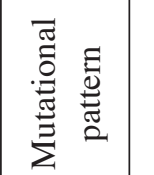

光

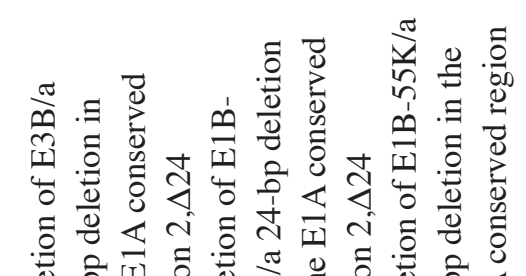

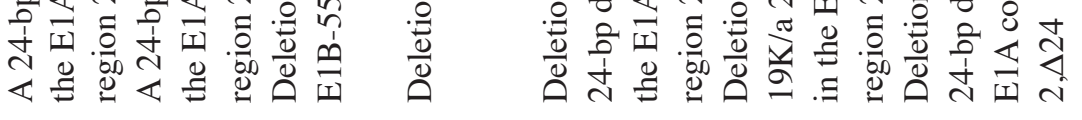

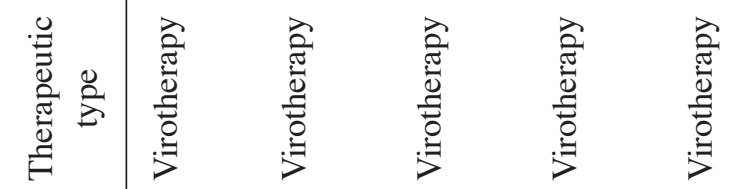

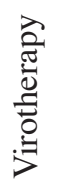

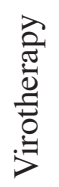

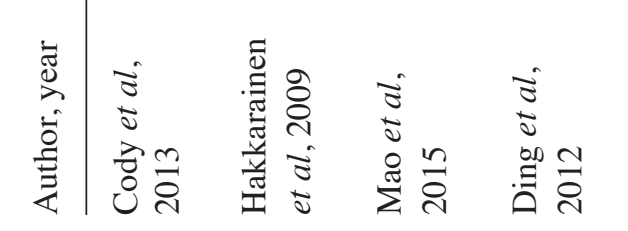

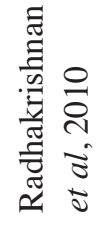

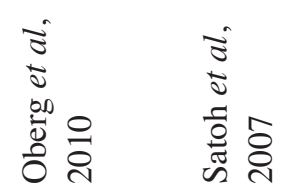




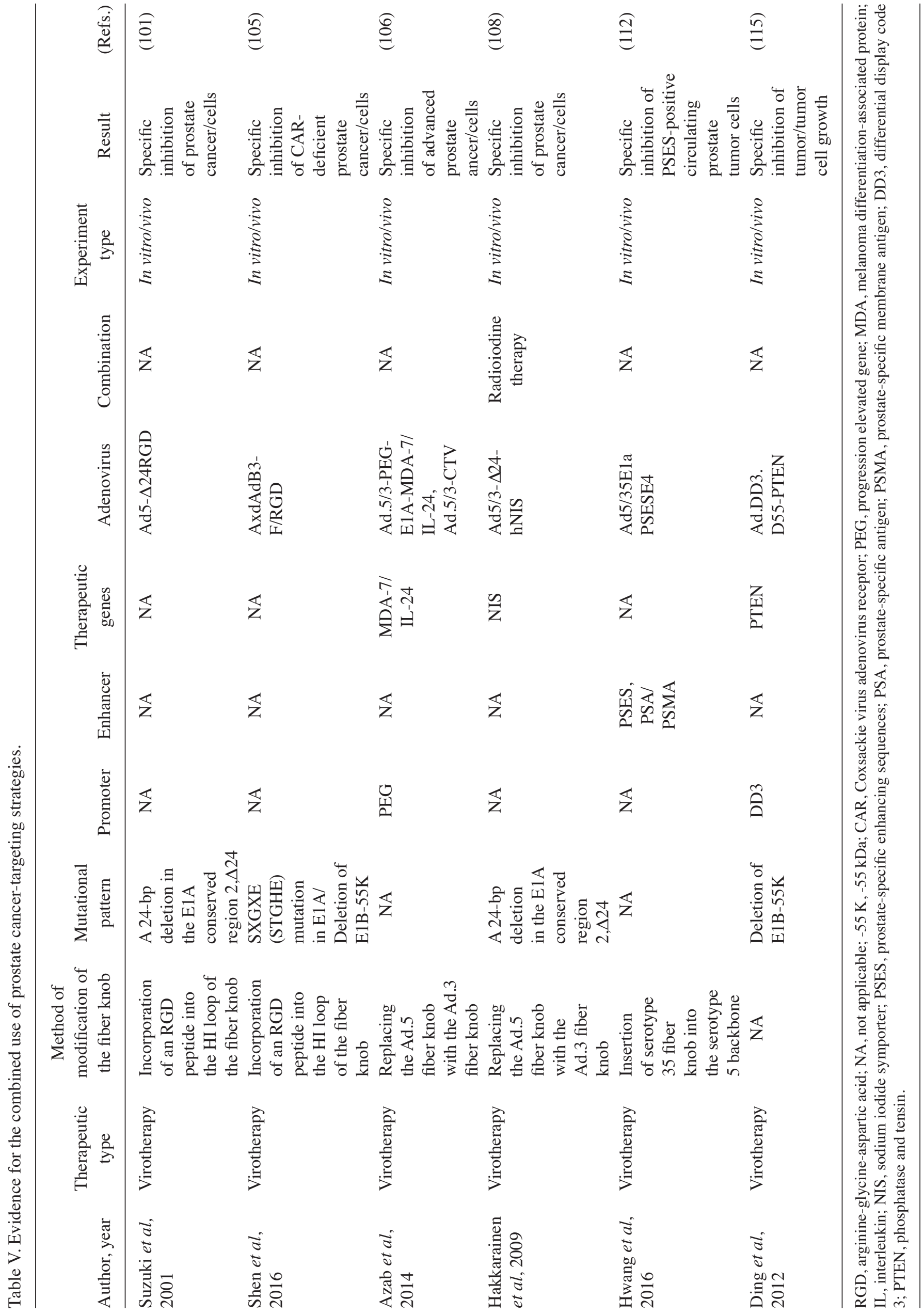


Another promising direction for tumor-targeting strategies takes advantage of the host immune system. The immune system is a potent defensive capability that protects the body from disease, including tumor development and progression. However, certain tumors exhibit host immune tolerance. Adenoviruses armed with cytokines or inhibitors are able to weaken tumor-associated immune checkpoint inhibition, and the host immune tolerance of the tumor may also be reduced (123-125). Following lysis of tumor cells infected by the adenovirus, tumor antigen exposure activates host tumor immunity to induce lysis of metastatic lesions (123). Several adenoviruses have been developed to trigger these oncolytic immunotherapeutic effects, and the results have been satisfactory in certain tumors. Adenovirus mutant Ad5 $\Delta 24 / 3-R G D-G M-C S F$, with expression of granulocyte macrophage-colony-stimulating factor (GM-CSF), exhibits potent antitumor effects in $\mathrm{PCa}$. This construct induced tumor cell death and activated T-cells in response to antigen presentation by exposure of the tumor antigen. The mounted immune response of the injected tumor improved immune recognition to attenuate the growth of distant metastases in PCa (123). Pexa-Vec, which is an oncolytic poxvirus expressing GM-CSF, markedly inhibited tumor progression by inducing host tumor immunity (124). A HSV-1 mutant, termed T-VEC, also expressed GM-CSF to activate antitumor immunity and induced regression of non-injected distal lesions in advanced melanoma (125). Although Pexa-Vec and T-VEC have not yet been used to treat $\mathrm{PCa}$, we hypothesize that treatment of PCa with adenoviruses constructed using an identical strategy may achieve beneficial responses. Adenoviruses armed with cytokines or inhibitors are the most promising strategy for the targeted treatment of earlyand late-stage $\mathrm{PCa}$.

\section{Conclusion}

In conclusion, the tumor-targeting effect is the key point regarding adenovirus-mediated gene therapy and virotherapy. Targeting strategies have been increasingly developed in basic research, however, various limitations remain. Therefore, further research concerning targeting strategies is required to improve the safety of these therapies in the human body and to maximize the net benefit of adenovirus-mediated gene therapy and virotherapy.

\section{Acknowledgements}

The present study was supported by the Talent Innovation and Enterprise Program of Lanzhou (grant no. 2015-RC-16).

\section{References}

1. Nadeau I and Kamen A: Production of adenovirus vector for gene therapy. Biotechnol Adv 20: 475-489, 2003.

2. Rowe WP, Huebner RJ, Gilmore LK, Parrott RH and Ward TG: Isolation of a cytopathogenic agent from human adenoids undergoing spontaneous degeneration in tissue culture. Proc Soc Exp Biol Med 84: 570-573, 1953.

3. Berkner KL: Development of adenovirus vectors for the expression of heterologous genes. Biotechniques 6: 616-629, 1988.

4. Berkner KL: Expression of heterologous sequences in adenoviral vectors. Curr Top Microbiol Immunol 158: 39-66, 1992.

5. Engelhardt JF, Ye X, Doranz B and Wilson JM: Ablation of E2A in recombinant adenoviruses improves transgene persistence and decreases inflammatory response in mouse liver. Proc Natl Acad Sci USA 91: 6196-6200, 1994.
6. Hehir KM, Armentano D, Cardoza LM, Choquette TL, Berthelette PB, White GA, Couture LA, Everton MB, Keegan J, Martin JM, et al: Molecular characterization of replication-competent variants of adenovirus vectors and genome modifications to prevent their occurrence. J Virol 70: 8459-8467, 1996.

7. Parks RJ and Graham FL: A helper-dependent system for adenovirus vector production helps define a lower limit for efficient DNA packaging. J Virol 71: 3293-3298, 1997.

8. Sato M, Suzuki S, Kubo S and Mitani K: Replication and packaging of helper-dependent adenoviral vectors. Gene Ther 9: 472-476, 2002.

9. Wilmott RW, Amin RS, Perez CR, Wert SE, Keller G, Boivin GP, Hirsch R, De Inocencio J, Lu P, Reising SF, et al: Safety of adenovirus-mediated transfer of the human cystic fibrosis transmembrane conductance regulator cDNA to the lungs of nonhuman primates. Hum Gene Ther 7: 301-318, 1996.

10. Fukazawa T, Matsuoka J, Yamatsuji T, Maeda Y, Durbin ML and Naomoto Y: Adenovirus-mediated cancer gene therapy and virotherapy (Review). Int J Mol Med 25: 3-10, 2010.

11. Bauerschmitz GJ, Barker SD and Hemminki A: Adenoviral gene therapy for cancer: From vectors to targeted and replication competent agents (Review). Int J Oncol 21: 1161-1174, 2002.

12. Jounaidi Y, Doloff JC and Waxman DJ: Conditionally replicating adenoviruses for cancer treatment. Curr Cancer Drug Targets 7: 285-301, 2007.

13. Power AT and Bell JC: Taming the Trojan horse: Optimizing dynamic carrier cell/oncolytic virus systems for cancer biotherapy. Gene Ther 15: 772-779, 2008.

14. Wei F, Wang H, Chen X, Li C and Huang Q: Dissecting the roles of E1A and E1B in adenoviral replication and RCAd-enhanced RDAd transduction efficacy on tumor cells. Cancer Biol Ther 15: 1358-1366, 2014.

15. Lee CH, Kasala D, Na Y,Lee MS, Kim SW, Jeong JH and Yun CO: Enhanced therapeutic efficacy of an adenovirus-PEI-bile-acid complex in tumors with low coxsackie and adenovirus receptor expression. Biomaterials 35: 5505-5516, 2014.

16. Heise C,Hermiston T, Johnson L, Brooks G,Sampson-Johannes A, Williams A, Hawkins L and Kirn D: An adenovirus E1A mutant that demonstrates potent and selective systemic anti-tumoral efficacy. Nat Med 6: 1134-1139, 2000.

17. Andriole GL, Crawford ED, Grubb RL III, Buys SS, Chia D, Church TR, Fouad MN, Gelmann EP, Kvale PA, Reding DJ, et al: Mortality results from a randomized prostate-cancer screening trial. N Engl J Med 360: 1310-1319, 2009.

18. Matsuyama H, Baba Y, Yamakawa G, Yamamoto $\mathrm{N}$ and Naito K: Diagnostic value of prostate-specific antigen-related parameters in discriminating prostate cancer. Int J Urol 7: 409-414, 2000.

19. Ravery V and Boccon-Gibod L: Free/total prostate-specific antigen ratio-hope and controversies. Eur Urol 31: 385-388, 1997.

20. Schröder FH, Hugosson J, Roobol MJ, Tammela TL, Ciatto S, Nelen V, Kwiatkowski M, Lujan M, Lilja H, Zappa M, et al: Screening and prostate-cancer mortality in a randomized European study. N Engl J Med 360: 1320-1328, 2009.

21. Yousef GM and Diamandis EP: The new human tissue kallikrein gene family: Structure, function, and association to disease. Endocr Rev 22: 184-204, 2001

22. Chen Y, DeWeese T, Dilley J, Zhang Y, Li Y, Ramesh N, Lee J, Pennathur-Das R, Radzyminski J, Wypych J, et al: CV706, a prostate cancer-specific adenovirus variant, in combination with radiotherapy produces synergistic antitumor efficacy without increasing toxicity. Cancer Res 61: 5453-5460, 2001.

23. Rodriguez R, Schuur ER, Lim HY, Henderson GA, Simons JW and Henderson DR: Prostate attenuated replication competent adenovirus (ARCA) CN706: A selective cytotoxic for prostate-specific antigen-positive prostate cancer cells. Cancer Res 57: 2559-2563, 1997.

24. DeWeese TL, van der Poel H,Li S, Mikhak B, Drew R, Goemann M, Hamper U, DeJong R, Detorie N, Rodriguez R, et al: A phase I trial of CV706, a replication-competent, PSA selective oncolytic adenovirus, for the treatment of locally recurrent prostate cancer following radiation therapy. Cancer Res 61: 7464-7472, 2001.

25. Wang L, Dong J, Wei M, Wen W, Gao J, Zhang Z and Qin W: Selective and augmented $\beta$-glucuronidase expression combined with DOX-GA3 application elicits the potent suppression of prostate cancer. Oncol Rep 35: 1417-1424, 2016.

26. Matuo Y, Nishi N, Negi T, Tanaka Y and Wada F: Isolation and characterization of androgen-dependent non-histone chromosomal protein from dorsolateral prostate of rats. Biochem Biophys Res Commun 109: 334-340, 1982. 
27. Spence AM, Sheppard PC, Davie JR, Matuo Y, Nishi N, McKeehan WL, Dodd JG and Matusik RJ: Regulation of a bifunctional mRNA results in synthesis of secreted and nuclear probasin. Proc Natl Acad Sci USA 86: 7843-7847, 1989.

28. Greenberg NM, DeMayo FJ, Sheppard PC, Barrios R, Lebovitz R, Finegold M, Angelopoulou R, Dodd JG, Duckworth ML, Rosen JM, et al: The rat probasin gene promoter directs hormonally and developmentally regulated expression of a heterologous gene specifically to the prostate in transgenic mice. Mol Endocrinol 8: 230-239, 1994.

29. Trujillo MA, Oneal MJ, McDonough S, Qin R and Morris JC: A probasin promoter, conditionally replicating adenovirus that expresses the sodium iodide symporter (NIS) for radiovirotherapy of prostate cancer. Gene Ther 17: 1325-1332, 2010.

30. Andriani F, Nan B, Yu J, Li X, Weigel NL, McPhaul MJ, Kasper S, Kagawa S, Fang B, Matusik RJ, et al: Use of the probasin promoter ARR2PB to express Bax in androgen receptor-positive prostate cancer cells. J Natl Cancer Inst 93: 1314-1324, 2001

31. Eder M, Eisenhut M, Babich J and Haberkorn U: PSMA as a target for radiolabelled small molecules. Eur J Nucl Med Mol Imaging 40: 819-823, 2013.

32. Heston WD: Significance of prostate-specific membrane antigen (PSMA). A neurocarboxypeptidase and membrane folate hydrolase. Urologe A 35: 400-407, 1996 (In German).

33. Minner S, Wittmer C, Graefen M, Salomon G, Steuber T, Haese A, Huland H, Bokemeyer C, Yekebas E, Dierlamm J, et al: High level PSMA expression is associated with early PSA recurrence in surgically treated prostate cancer. Prostate 71: 281-288, 2011.

34. Rinker-Schaeffer CW, Hawkins AL, Su SL, Israeli RS Griffin CA, Isaacs JT and Heston WD: Localization and physical mapping of the prostate-specific membrane antigen (PSM) gene to human chromosome 11. Genomics 30: 105-108, 1995.

35. Ross JS, Sheehan CE, Fisher HA, Kaufman RP Jr, Kaur P, Gray K, Webb I, Gray GS, Mosher R and Kallakury BV: Correlation of primary tumor prostate-specific membrane antigen expression with disease recurrence in prostate cancer. Clin Cancer Res 9: 6357-6362, 2003

36. Sweat SD, Pacelli A, Murphy GP and Bostwick DG: Prostatespecific membrane antigen expression is greatest in prostate adenocarcinoma and lymph node metastases. Urology 52: 637-640, 1998

37. Zhang Y, Guo Z, Du T, Chen J, Wang W, Xu K, Lin T and Huang H: Prostate specific membrane antigen (PSMA): A novel modulator of $\mathrm{p} 38$ for proliferation, migration, and survival in prostate cancer cells. Prostate 73: 835-841,2013.

38. Gao XF, Zhou T, Chen GH, Xu CL, Ding YL and Sun YH: Radioiodine therapy for castration-resistant prostate cancer following prostate-specific membrane antigen promoter-mediated transfer of the human sodium iodide symporter. Asian J Androl 16: 120-123, 2014.

39. Zeng H, Wei Q, Huang R, Chen N, Dong Q, Yang Y and Zhou Q: Recombinant adenovirus mediated prostate-specific enzyme pro-drug gene therapy regulated by prostate-specific membrane antigen (PSMA) enhancer/promoter. J Androl 28: $827-835,2007$

40. Bussemakers MJ, van Bokhoven A, Verhaegh GW, Smit FP, Karthaus HF, Schalken JA, Debruyne FM, Ru N and Isaacs WB: DD3: A new prostate-specific gene, highly overexpressed in prostate cancer. Cancer Res 59: 5975-5979, 1999.

41. de Kok JB, Verhaegh GW, Roelofs RW, Hessels D, Kiemeney LA, Aalders TW, Swinkels DW and Schalken JA: DD3 (PCA3), a very sensitive and specific marker to detect prostate tumors. Cancer Res 62: 2695-2698, 2002.

42. Hessels D, Klein Gunnewiek JM, van Oort I, Karthaus HF van Leenders GJ, van Balken B, Kiemeney LA, Witjes JA and Schalken JA: DD3(PCA3)-based molecular urine analysis for the diagnosis of prostate cancer. Eur Urol 44: 8-16, 2003.

43. Fan JK, Wei N, Ding M, Gu JF, Liu XR, Li BH, Qi R, Huang WD, Li YH, Xiong XQ, et al: Targeting Gene-ViroTherapy for prostate cancer by DD3-driven oncolytic virus-harboring interleukin-24 gene. Int J Cancer 127: 707-717, 2010.

44. Mao LJ, Zheng JN, Li W, Wang JQ, Chen JC and Sun XQ: Construction of an oncolytic adenovirus expressing small hairpin RNA and targeting the SATB1 gene. Zhonghua Nan Ke Xue 16: 679-683, 2010 (In Chinese).

45. Bodnar AG, Ouellette M, Frolkis M, Holt SE, Chiu CP, Morin GB, Harley CB, Shay JW, Lichtsteiner S and Wright WE: Extension of life-span by introduction of telomerase into normal human cells. Science 279: 349-352, 1998.
46. Cong YS, Wen J and Bacchetti S: The human telomerase catalytic subunit hTERT: Organization of the gene and characterization of the promoter. Hum Mol Genet 8: 137-142, 1999.

47. Gu J, Andreeff M, Roth JA and Fang B: hTERT promoter induces tumor-specific Bax gene expression and cell killing in syngenic mouse tumor model and prevents systemic toxicity. Gene Ther 9: 30-37, 2002.

48. Kyo S, Kanaya T, Takakura M, Tanaka M, Yamashita A, Inoue H and Inoue M: Expression of human telomerase subunits in ovarian malignant, borderline and benign tumors. Int J Cancer 80: 804-809, 1999

49. Bostwick DG: Prospective origins of prostate carcinoma. Prostatic intraepithelial neoplasia and atypical adenomatous hyperplasia. Cancer 78: 330-336, 1996.

50. Iczkowski KA, Pantazis CG, McGregor DH, Wu Y and Tawfik OW: Telomerase reverse transcriptase subunit immunoreactivity: A marker for high-grade prostate carcinoma. Cancer 95: 2487-2493, 2002

51. Paradis V, Dargère D, Laurendeau I, Benoît G, Vidaud M, Jardin A and Bedossa P: Expression of the RNA component of human telomerase (hTR) in prostate cancer, prostatic intraepithelial neoplasia, and normal prostate tissue. J Pathol 189: 213-218, 1999.

52. Zhang W, Kapusta LR, Slingerland JM and Klotz LH: Telomerase activity in prostate cancer, prostatic intraepithelial neoplasia, and benign prostatic epithelium. Cancer Res 58: 619-621, 1998.

53. Sato D, Kurihara Y, Kondo S, Shirota T, Urata Y, Fujiwara T and Shintani S: Antitumor effects of telomerase-specific replication-selective oncolytic viruses for adenoid cystic carcinoma cell lines. Oncol Rep 30: 2659-2664, 2013.

54. Tazawa H, Kagawa S and Fujiwara T: Oncolytic adenovirusinduced autophagy: Tumor-suppressive effect and molecular basis. Acta Med Okayama 67: 333-342, 2013.

55. Yano S, Tazawa H, Hashimoto Y, Shirakawa Y, Kuroda S, Nishizaki M, Kishimoto H, Uno F, Nagasaka T, Urata Y, et al: A genetically engineered oncolytic adenovirus decoys and lethally traps quiescent cancer stem-like cells in S/G2/M phases. Clin Cancer Res 19: 6495-6505, 2013.

56. Yano S, Miwa S, Kishimoto H, Urata Y, Tazawa H, Kagawa S, Bouvet M, Fujiwara T and Hoffman RM: Eradication of osteosarcoma by fluorescence-guided surgery with tumor labeling by a killer-reporter adenovirus. J Orthop Res 34: 836-844, 2016.

57. Yano S, Takehara K, Miwa S, Kishimoto H, Hiroshima Y, Murakami T, Urata Y, Kagawa S, Bouvet M, Fujiwara T and Hoffman RM: Improved resection and outcome of colon-cancer liver metastasis with fluorescence-guided surgery using in situ GFP labeling with a telomerase-dependent adenovirus in an orthotopic mouse model. PLoS One 11: e0148760, 2016.

58. Yano S, Takehara K, Miwa S, Kishimoto H, Tazawa $\mathrm{H}$, Urata Y, Kagawa S, Bouvet M, Fujiwara T and Hoffman RM: Fluorescence-guided surgery of a highly-metastatic variant of human triple-negative breast cancer targeted with a cancer-specific GFP adenovirus prevents recurrence. Oncotarget 7: 75635-75647, 2016.

59. Huang P, Watanabe M, Kaku H, Kashiwakura Y, Chen J, Saika T, Nasu Y, Fujiwara T, Urata Y and Kumon H: Direct and distant antitumor effects of a telomerase-selective oncolytic adenoviral agent, OBP-301, in a mouse prostate cancer model. Cancer Gene Ther 15: 315-322, 2008.

60. Zhang Y, Qi JC, Lian WF, Cai WQ, Li W and Liu KL: The animal research of recombinant adenovirus controlled by human telomerase reverse transcriptase promoter in the treatment of human prostate cancer. Zhonghua Wai Ke Za Zhi 44: 1252-1255, 2006 (In Chinese).

61. Bhang HE, Gabrielson KL, Laterra J, Fisher PB and Pomper MG: Tumor-specific imaging through progression elevated gene-3 promoter-driven gene expression. Nat Med 17: 123-129, 2011.

62. Greco A, Di Benedetto A, Howard CM, Kelly S, Nande R, Dementieva Y, Miranda M, Brunetti A, Salvatore M, Claudio L, et al: Eradication of therapy-resistant human prostate tumors using an ultrasound-guided site-specific cancer terminator virus delivery approach. Mol Ther 18: 295-306, 2010.

63. Sarkar D, Su ZZ, Vozhilla N, Park ES, Gupta P and Fisher PB: Dual cancer-specific targeting strategy cures primary and distant breast carcinomas in nude mice. Proc Natl Acad Sci USA 102: 14034-14039, 2005.

64. Su ZZ, Sarkar D, Emdad L, Duigou GJ, Young CS, Ware J, Randolph A, Valerie K and Fisher PB: Targeting gene expression selectively in cancer cells by using the progression-elevated gene-3 promoter. Proc Natl Acad Sci USA 102: 1059-1064, 2005. 
65. Su ZZ, Shi Y and Fisher PB: Subtraction hybridization identifies a transformation progression-associated gene PEG-3 with sequence homology to a growth arrest and DNA damage-inducible gene. Proc Natl Acad Sci USA 94: 9125-9130, 1997.

66. Sarkar D, Lebedeva IV, Su ZZ, Park ES, Chatman L, Vozhilla N, Dent P, Curiel DT and Fisher PB: Eradication of therapy-resistant human prostate tumors using a cancer terminator virus. Cancer Res 67: 5434-5442, 2007.

67. Fisher LW, Whitson SW, Avioli LV and Termine JD: Matrix sialoprotein of developing bone. J Biol Chem 258: 12723-12727, 1983.

68. Tye CE, Rattray KR, Warner KJ, Gordon JA, Sodek J, Hunter GK and Goldberg HA: Delineation of the hydroxyapatite-nucleating domains of bone sialoprotein. J Biol Chem 278 7949-7955, 2003.

69. Fedarko NS, Jain A, Karadag A, Van Eman MR and Fisher LW: Elevated serum bone sialoprotein and osteopontin in colon, breast, prostate, and lung cancer. Clin Cancer Res 7: 4060-4066, 2001.

70. Tu Q, Zhang J, Fix A, Brewer E, Li YP, Zhang ZY and Chen J: Targeted overexpression of BSP in osteoclasts promotes bone metastasis of breast cancer cells. J Cell Physiol 218: 135-145, 2009.

71. Waltregny D, Bellahcène A, Van Riet I, Fisher LW, Young M, Fernandez P, Dewé W, de Leval J and Castronovo V: Prognostic value of bone sialoprotein expression in clinically localized human prostate cancer. J Natl Cancer Inst 90: 1000-1008, 1998.

72. Canales BK, Li Y, Thompson MG, Gleason JM, Chen Z, Malaeb B, Corey DR, Herbert BS, Shay JW and Koeneman KS: Small molecule, oligonucleotide-based telomerase template inhibition in combination with cytolytic therapy in an in vitro androgen-independent prostate cancer model. Urol Oncol 24: 141-151, 2006

73. Li Y, Kacka M, Thompson M, Hsieh JT and Koeneman KS: Conditionally replicating adenovirus therapy utilizing bone sialoprotein promoter (Ad-BSP-E1a) in an in vivo study of treating androgen-independent intraosseous prostate cancer. Urol Oncol 29: 624-633, 2011.

74. Shariat SF, Semjonow A, Lilja H, Savage C, Vickers AJ and Bjartell A: Tumor markers in prostate cancer I: Blood-based markers. Acta Oncol 50 (Suppl 1): S61-S75, 2011.

75. Vickers AJ, Cronin AM, Roobol MJ, Savage CJ, Peltola M, Pettersson K, Scardino PT, Schröder FH and Lilja H: A four-kallikrein panel predicts prostate cancer in men with recent screening: Data from the European randomized study of screening for prostate cancer, rotterdam. Clin Cancer Res 16: $3232-3239,2010$

76. Jansen FH, Roobol M, Jenster G, Schröder FH and Bangma CH: Screening for prostate cancer in 2008 II: The importance of molecular subforms of prostate-specific antigen and tissue kallikreins. Eur Urol 55: 563-574, 2009.

77. Steuber T, Vickers AJ, Haese A, Becker C, Pettersson K Chun FK, Kattan MW, Eastham JA, Scardino PT, Huland H and Lilja $\mathrm{H}$ : Risk assessment for biochemical recurrence prior to radical prostatectomy: Significant enhancement contributed by human glandular kallikrein 2 (hK2) and free prostate specific antigen (PSA) in men with moderate PSA-elevation in serum. Int J Cancer 118: 1234-1240, 2006.

78. Mattsson JM, Ravela S, Hekim C, Jonsson M, Malm J, Närvänen A, Stenman UH and Koistinen H: Proteolytic activity of prostate-specific antigen (PSA) towards protein substrates and effect of peptides stimulating PSA activity. PLoS One 9: e107819, 2014

79. Yu DC, Sakamoto GT and Henderson DR: Identification of the transcriptional regulatory sequences of human kallikrein 2 and their use in the construction of calydon virus 764, an attenuated replication competent adenovirus for prostate cancer therapy. Cancer Res 59: 1498-1504, 1999.

80. Gardner TA, Lee SJ, Lee SD, Li X, Shirakawa T, Kwon DD, Park RY, Ahn KY and Jung C: Differential expression of osteocalcin during the metastatic progression of prostate cancer. Oncol Rep 21: 903-908, 2009.

81. Hagberg Thulin M, Jennbacken K, Damber JE and Welén K: Osteoblasts stimulate the osteogenic and metastatic progression of castration-resistant prostate cancer in a novel model for in vitro and in vivo studies. Clin Exp Metastasis 31: 269-283, 2014.

82. Koizumi M, Yonese J, Fukui I and Ogata E: Metabolic gaps in bone formation may be a novel marker to monitor the osseous metastasis of prostate cancer. J Urol 167: 1863-1866, 2002.
83. Nimptsch K, Rohrmann S, Nieters A and Linseisen J: Serum undercarboxylated osteocalcin as biomarker of vitamin $\mathrm{K}$ intake and risk of prostate cancer: A nested case-control study in the Heidelberg cohort of the European prospective investigation into cancer and nutrition. Cancer Epidemiol Biomarkers Prev 18: 49-56, 2009

84. Pi M and Quarles LD: GPRC6A regulates prostate cancer progression. Prostate 72: 399-409, 2012.

85. Koeneman KS, Kao C, Ko SC, Yang L, Wada Y, Kallmes DF, Gillenwater JY, Zhau HE, Chung LW and Gardner TA: Osteocalcin-directed gene therapy for prostate-cancer bone metastasis. World J Urol 18: 102-110, 2000.

86. Kubo H, Gardner TA, Wada Y, Koeneman KS, Gotoh A, Yang L, Kao C, Lim SD, Amin MB, Yang H, et al: Phase I dose escalation clinical trial of adenovirus vector carrying osteocalcin promoter-driven herpes simplex virus thymidine kinase in localized and metastatic hormone-refractory prostate cancer. Hum Gene Ther 14: 227-241, 2003.

87. Matsubara S, Wada Y, Gardner TA, Egawa M, Park MS, Hsieh CL, Zhau HE, Kao C, Kamidono S, Gillenwater JY and Chung LW: A conditional replication-competent adenoviral vector, Ad-OC-Ela, to cotarget prostate cancer and bone stroma in an experimental model of androgen-independent prostate cancer bone metastasis. Cancer Res 61: 6012-6019, 2001.

88. Hsieh CL, Yang L, Miao L, Yeung F, Kao C, Yang H, Zhau HE and Chung LW: A novel targeting modality to enhance adenoviral replication by vitamin $\mathrm{D}(3)$ in androgen-independent human prostate cancer cells and tumors. Cancer Res 62: 3084-3092, 2002.

89. Dash R, Su ZZ, Lee SG, Azab B, Boukerche H, Sarkar D and Fisher PB: Inhibition of AP-1 by SARI negatively regulates transformation progression mediated by CCN1. Oncogene 29: 4412-4423, 2010.

90. Harris LG, Pannell LK, Singh S, Samant RS and Shevde LA: Increased vascularity and spontaneous metastasis of breast cancer by hedgehog signaling mediated upregulation of cyr61. Oncogene 31: 3370-3380, 2012.

91. Lv H, Fan E, Sun S, Ma X, Zhang X, Han DM and Cong YS Cyr61 is up-regulated in prostate cancer and associated with the p53 gene status. J Cell Biochem 106: 738-744, 2009.

92. Sarkar S, Quinn BA, Shen XN, Dash R, Das SK, Emdad L, Klibanov AL, Wang XY, Pellecchia M, Sarkar D and Fisher PB Therapy of prostate cancer using a novel cancer terminator virus and a small molecule BH-3 mimetic. Oncotarget 6: 10712-10727, 2015.

93. Lee SJ, Kim HS, Yu R, Lee K, Gardner TA, Jung C, Jeng MH, Yeung F, Cheng L and Kao C: Novel prostate-specific promoter derived from PSA and PSMA enhancers. Mol Ther 6: 415-421, 2002.

94. Adamson RE, Frazier AA, Evans H, Chambers KF, Schenk E, Essand M, Birnie R, Mitry RR, Dhawan A and Maitland NJ: In vitro primary cell culture as a physiologically relevant method for preclinical testing of human oncolytic adenovirus. Hum Gene Ther 23: 218-30, 2012.

95. Cheng WS, Dzojic H, Nilsson B, Totterman TH and Essand M An oncolytic conditionally replicating adenovirus for hormonedependent and hormone-independent prostate cancer. Cancer Gene Ther 13: 13-20, 2006.

96. Danielsson A, Dzojic H, Nilsson B and Essand M: Increased therapeutic efficacy of the prostate-specific oncolytic adenovirus $\mathrm{Ad}[\mathrm{I} / \mathrm{PPT}-\mathrm{E} 1 \mathrm{~A}]$ by reduction of the insulator size and introduction of the full-length E3 region. Cancer Gene Ther 15: 203-213, 2008

97. Dzojic H, Cheng WS and Essand M: Two-step amplification of the human PPT sequence provides specific gene expression in an immunocompetent murine prostate cancer model. Cancer Gene Ther 14: 233-240, 2007.

98. Cheng WS, Kraaij R, Nilsson B, van der Weel L, de Ridder CM Totterman TH and Essand M: A novel TARP-promoter-based adenovirus against hormone-dependent and hormone-refractory prostate cancer. Mol Ther 10: 355-364, 2004.

99. Kraaij R, van der Weel L, de Ridder CM, van der Korput HA, Zweistra JL, van Rijswijk AL, Bangma CH and Trapman J: A small chimeric promoter for high prostate-specific transgene expression from adenoviral vectors. Prostate 67: 829-839, 2007

100. Liu C, Zhang Y, Liu MM, Zhou H, Chowdhury W, Lupold SE, Deweese TL and Rodriguez R: Evaluation of continuous low dose rate versus acute single high dose rate radiation combined with oncolytic viral therapy for prostate cancer. Int J Radiat Biol 86: 220-229, 2010. 
101. Suzuki K, Fueyo J, Krasnykh V, Reynolds PN, Curiel DT and Alemany R: A conditionally replicative adenovirus with enhanced infectivity shows improved oncolytic potency. Clin Cancer Res 7: 120-126, 2001.

102. Cody JJ, Rivera AA, Lyons GR, Yang SW, Wang M, Ashley JW, Meleth S, Feng X, Siegal GP and Douglas JT: Expression of osteoprotegerin from a replicating adenovirus inhibits the progression of prostate cancer bone metastases in a murine model. Lab Invest 93: 268-278, 2013.

103. Dong W, van Ginkel JW, Au KY, Alemany R, Meulenberg JJ and van Beusechem VW: ORCA-010, a novel potency-enhanced oncolytic adenovirus, exerts strong antitumor activity in preclinical models. Hum Gene Ther 25: 897-904, 2014

104. Magnusson MK, Kraaij R, Leadley RM, De Ridder CM, van Weerden WM, Van Schie KA, Van der Kroeg M, Hoeben RC, Maitland NJ and Lindholm L: A transductionally retargeted adenoviral vector for virotherapy of Her $2 /$ neu-expressing prostate cancer. Hum Gene Ther 23: 70-82, 2012.

105. Shen YH, Yang F, Wang H, Cai ZJ, Xu YP, Zhao A, Su Y, Zhang G and Zhu SX: Arg-Gly-Asp (RGD)-modified E1A/E1B double mutant adenovirus enhances antitumor activity in prostate cancer cells in vitro and in mice. PLoS One 11: e0147173, 2016.

106. Azab BM, Dash R, Das SK, Bhutia SK, Sarkar S, Shen XN, Quinn BA, Dent P, Dmitriev IP, Wang XY, et al: Enhanced prostate cancer gene transfer and therapy using a novel serotype chimera cancer terminator virus (Ad.5/3-CTV). J Cell Physiol 229: 34-43, 2014.

107. Oneal MJ, Trujillo MA, Davydova J, McDonough S, Yamamoto M and Morris JC III: Effect of increased viral replication and infectivity enhancement on radioiodide uptake and oncolytic activity of adenovirus vectors expressing the sodium iodide symporter. Cancer Gene Ther 20: 195-200, 2013.

108. Hakkarainen T, Rajecki M, Sarparanta M, Tenhunen M, Airaksinen AJ, Desmond RA, Kairemo K and Hemminki A: Targeted radiotherapy for prostate cancer with an oncolytic adenovirus coding for human sodium iodide symporter. Clin Cancer Res 15: 5396-5403, 2009

109. Rajecki M, Kanerva A, Stenman UH, Tenhunen M, Kangasniemi L, Särkioja M, Ala-Opas MY, Alfthan H, Sankila A, Rintala E et al: Treatment of prostate cancer with Ad5/3Delta24hCG allows non-invasive detection of the magnitude and persistence of virus replication in vivo. Mol Cancer Ther 6: 742-751, 2007.

110. Xu W, Zhang Z, Yang Y, Hu Z, Wang CH, Morgan M, Wu Y, Hutten R, Xiao X, Stock S, et al: Ad5/48 hexon oncolytic virus expressing STGF $\beta$ RIIFc produces reduced hepatic and systemic toxicities and inhibits prostate cancer bone metastases. Mol Ther 22: 1504-1517, 2014.

111. Kim JS, Lee SD, Lee SJ and Chung MK: Development of an immunotherapeutic adenovirus targeting hormone-independent prostate cancer. Onco Targets Ther 6: 1635-1642, 2013.

112. Hwang JE, Joung JY, Shin SP, Choi MK, Kim JE, Kim YH, Park WS, Lee SJ and Lee KH: Ad5/35E1aPSESE4: A novel approach to marking circulating prostate tumor cells with a replication competent adenovirus controlled by PSA/PSMA transcription regulatory elements. Cancer Lett 372: 57-64, 2016.

113. Heise C, Sampson-Johannes A, Williams A, McCormick F, Von Hoff DD and Kirn DH: ONYX-015, an E1B gene-attenuated adenovirus, causes tumor-specific cytolysis and antitumoral efficacy that can be augmented by standard chemotherapeutic agents. Nat Med 3: 639-645, 1997.

114. Mao LJ, Zhang J, Liu N, Fan L, Yang DR, Xue BX, Shan YX and Zheng JN: Oncolytic virus carrying shRNA targeting SATB1 inhibits prostate cancer growth and metastasis. Tumour Biol 36: 9073-9081, 2015.

115. Ding M, Cao X, Xu HN, Fan JK, Huang HL, Yang DQ, Li YH, Wang J, Li R and Liu XY: Prostate cancer-specific and potent antitumor effect of a DD3-controlled oncolytic virus harboring the PTEN gene. PLoS One 7: e35153, 2012.

116. Radhakrishnan S, Miranda E, Ekblad M,Holford A,Pizarro MT, Lemoine NR and Halldén G: Efficacy of oncolytic mutants targeting $\mathrm{pRb}$ and $\mathrm{p} 53$ pathways is synergistically enhanced when combined with cytotoxic drugs in prostate cancer cells and tumor xenografts. Hum Gene Ther 21: 1311-1325, 2010.
117. Oberg D, Yanover E, Adam V, Sweeney K, Costas C, Lemoine NR and Halldén G: Improved potency and selectivity of an oncolytic E1ACR2 and E1B19K deleted adenoviral mutant in prostate and pancreatic cancers. Clin Cancer Res 16: 541-553, 2010.

118. Satoh M, Wang H, Ishidoya $S$, Abe H, Moriya T, Hamada $H$ and Arai Y: Oncolytic virotherapy for prostate cancer by E1A, E1B mutant adenovirus. Urology 70: 1243-1248, 2007.

119. DeWeese TL, van der Poel H, Li S, Mikhak B, Drew R, Goemann M,Hamper U, DeJong R, Detorie N, Rodriguez R, et al: A phase I trial of CV706, a replication-competent, PAS selective oncolytic adenovirus, for the treatment of locally recurrent prostate cancer following radiation therapy. Cancer Res 61: 7464-7472, 2001.

120. Freytag SO, Khil M, Stricker H, Peabody J, Menon M, DePeralta-Venturina M, Nafziger D, Pegg J, Paielli D, Brown S, et al: Phase I study of replication-competent adenovirus-mediated double suicide gene therapy for the treatment of locally recurrent prostate cancer. Cancer Res 62: 4968-4976, 2002.

121. Freytag SO, Stricker H, Peabody J, Pegg J, Paielli D, Movsas B, Barton KN, Brown SL, Lu M and Kim JH: Five-year follow-up of trial of replication-competent adenovirus-mediated suicide gene therapy for treatment of prostate cancer. Mol Ther 15 . 636-642, 2007.

122. Small EJ, Carducci MA, Burke JM, Rodriguez R, Fong L, van Ummersen L, Yu DC, Aimi J, Ando D, Working P, et al: A phase I trial of intravenous CG7870, a replication-selective, prostate-specific antigen-targeted oncolytic adenovirus, for the treatment of hormone-refractory, metastatic prostate cancer. Mol Ther 14: 107-117, 2006

123. Kanerva A, Nokisalmi P, Diaconu I, Koski A, Cerullo V, Liikanen I, Tähtinen S, Oksanen M, Heiskanen R, Pesonen S, et al: Antiviral and antitumor T-cell immunity in patients treated with GM-CSF-coding oncolytic adenovirus. Clin Cancer Res 19: 2734-72744, 2013

124. Breitbach CJ, Burke J, Jonker D, Stephenson J, Haas AR, Chow LQ, Nieva J, Hwang TH, Moon A, Patt R, et al: Intravenous delivery of a multi-mechanistic cancer-targeted oncolytic poxvirus in humans. Nature 477: 99-102, 2011.

125. Harrington KJ, Puzanov I, Hecht JR, Hodi FS, Szabo Z, Murugappan S and Kaufman HL: Clinical development of talimogene laherparepvec (T-VEC): A modified herpes simplex virus type-1-derived oncolytic immunotherapy. Expert Rev Anticancer Ther 15: 1389-1403, 2015.

126. Lu Y, Zhang Y, Chang G and Zhang J: Comparison of prostate-specific promoters and the use of PSP-driven virotherapy for prostate cancer. Biomed Res Int 2013: 624632, 2013.

127. Martiniello-Wilks R, Tsatralis T, Russell P, Brookes DE, Zandvliet D, Lockett LJ, Both GW, Molloy PL and Russell PJ: Transcription-targeted gene therapy for androgen-independent prostate cancer. Cancer Gene Ther 9: 443-452, 2002.

128. Zhang M, Wang J, Li C, Hu N, Wang K, Ji H, He D, Quan C, Li X, Jin N and Li Y: Potent growth-inhibitory effect of a dual cancer-specific oncolytic adenovirus expressing apoptin on prostate carcinoma. Int J Oncol 42: 1052-1060, 2013.

129. Xie X, Zhao X, Liu Y, Young CY, Tindall DJ, Slawin KM and Spencer DM: Robust prostate-specific expression for targeted gene therapy based on the human kallikrein 2 promoter. Hum Gene Ther 12: 549-561, 2001.

130. Li X, Zhang YP, Kim HS, Bae KH, Stantz KM, Lee SJ, Jung C, Jiménez JA, Gardner TA, Jeng MH and Kao C: Gene therapy for prostate cancer by controlling adenovirus E1a and E4 gene expression with PSES enhancer. Cancer Res 65: 1941-1951, 2005.

131. Jimenez JA, Li X, Zhang YP, Bae KH, Mohammadi Y, Pandya P, Kao C and Gardner TA: Antitumor activity of Ad-IU2, a prostate-specific replication-competent adenovirus encoding the apoptosis inducer, TRAIL. Cancer Gene Ther 17: 180-191, 2010. 